\title{
37. GENERAL IMPLICATIONS OF THE LEG 49 DRILLING PROGRAM FOR NORTH ATLANTIC OCEAN GEOLOGY
}

\author{
Bruce P. Luyendyk, Department of Geological Sciences, University of California, Santa Barbara, California, \\ Alexander Shor, MIT/WHOI Joint Program in Oceanography, Woods Hole Oceanographic Institution, \\ Woods Hole, Massachusetts \\ and \\ J. R. Cann, Department of Geology, University of Newcastle upon Tyne, Newcastle, England
}

\begin{abstract}
General geological results of the Leg 49 drilling program are discussed without emphasis on petrologic and geochemical data. Three holes $(407$, 408 , and 409; Figure 1) were drilled on the west flank of Reykjanes Ridge. Our results suggest that the ridge has been anomalously shallow, relative to the worldwide average ridge depth, since at least $36 \mathrm{~m}$.y. ago (anomaly 13). It is clear, however, that thermal or tectonic events during the past 17 million years have perturbed the ridge depth profile, and perhaps bias the simple backtracking results for older crust toward anomalously shallow depths. On the basis of our results, regional uplift, with an average vertical component of up to 25 meters per million years since $36 \mathrm{~m} . \mathrm{y}$. ago, is possible and cannot be excluded.

Other holes are close to the crest of the Mid-Atlantic Ridge (410 and $410 \mathrm{~A}$ ) or in the rift valley itself (411). None of the ridge-crest sites (including 409) shows evidence of hydrothermal alteration and all rocks are extremely fresh. Magnetic properties show evidence of oxidation of Hole 410A basalts, however. Generally, all sites show a degree of alteration which correlates strongly with age, suggesting long-term reaction between basalts and cold sea water. Two sites, 412 and 413 , are in fracture zone $B$ in the FAMOUS area. The rocks here are generally fresh and unaltered basalts similar to rocks recovered from the rift mountains by dredging and during Leg 37 . Even though Site 412 is in the north side of the valley and 413 is in the south, they are both the same age, and match the age of the magnetic anomaly on the young (north) side of the valley.
\end{abstract}

\section{INTRODUCTION}

In this paper we discuss a variety of geologic topics related to the Leg 49 drilling program. The principal results of the program are outlined in the introductory chapter of this volume (Luyendyk, Cann, and Sharman); detailed overviews and syntheses of biostratigraphic, paleoenvironmental, geochemical and paleomagnetic results are discussed in this volume by Poore et al., Shore and Poore, Cann et al., and Steiner et al. Some of the topics dealt with here include the tectonics of the Reykjanes Ridge, the relationship of drilling at Sites 409,410 , and 411 to ridge-crest geology, and the implications of results from Sites 412 and 413 , in fracture zone $B$, with regard to fracture-zone geology.

\section{DRILLING ON THE REYKJANES RIDGE}

\section{Tectonic Framework of the Reykjanes Ridge}

The Reykjanes Ridge spreading center is now between the North Atlantic and European plates (Figure 1), but during its early history it lay between the Greenland and European plates (Kristoffersen and Talwani, 1977).
Separation between Greenland and Europe began at anomaly 24 time (56 m.y.B.P.), and sea-floor spreading was occurring simultaneously in the Norwegian Sea, Labrador Sea, and North Atlantic until about anomaly 20 (46 m.y.B.P.). After this, the Greenland plate welded to the North American. Opening on the Reykjanes Ridge has been relatively continuous since then, but north of Iceland the plate boundary jumped west to the coast of Greenland after anomaly 13 time (36 m.y.B.P.) (Talwani and Eldholm, 1977). Prior to this time, the spreading center south of the Jan Mayen fracture zone was offset to the east, relative to the Reykjanes Ridge, and this jump served to align the two.

Vogt and Avery (1974) have determined that spreading rates decreased fairly continuously on the Reykjanes Ridge, from $1.7 \mathrm{~cm} /$ year $60 \mathrm{~m} . \mathrm{y}$. ago to a minimum of $0.7 \mathrm{~cm} /$ year around $30 \mathrm{~m} . \mathrm{y}$. ago, and then increased to about 1.0 $\mathrm{cm} /$ year. They also note that between about 40 and $20 \mathrm{~m}$.y. ago the ridge flanks were broken by numerous fracture zones spaced about 100 kilometers apart. They suggest that this was caused by readjustment of spreading directions in response to the welding of the Greenland plate onto the North American. 


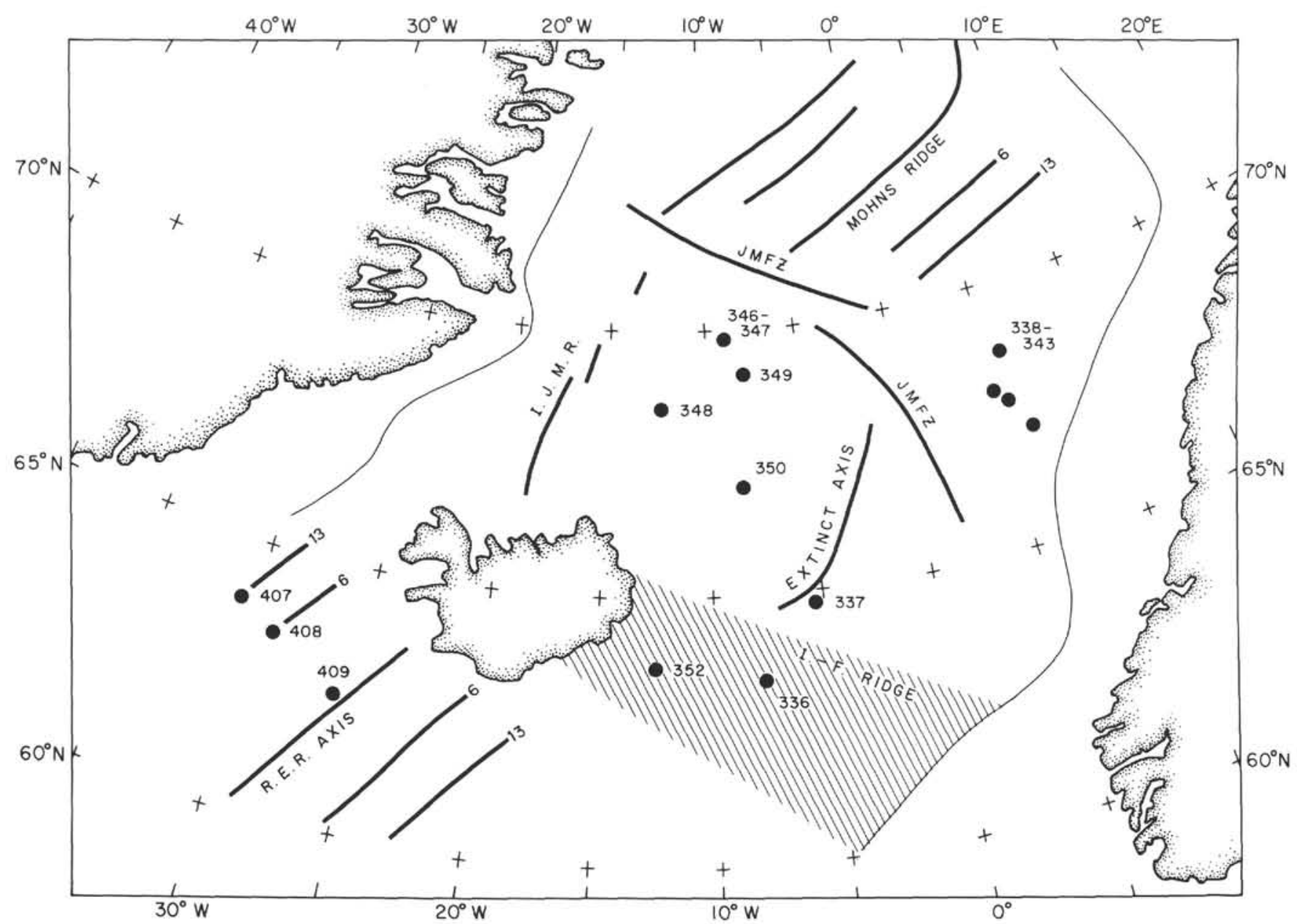

Figure 1. Locations of Leg 49 and Leg 38 drilling sites in the North Atlantic and the Norwegian Sea. Locations of anomalies 13 and 6 and the central anomaly are from Talwani and Eldholm (1977). JMFZ = Jan Mayen fracture zone, IJMR = Iceland-Jan Mayen Ridge, RER = Reykjanes Ridge. Shaded area is Iceland-Faeroes Ridge.

\section{Paleogeography of the Reykjanes Ridge}

At anomaly 13 time (Site 407), the Norwegian-Greenland Sea was open to only about 500 kilometers (Figure $2 \mathrm{a}$ ). The Reykjanes Ridge spreading center abutted the Iceland-Faeroe Ridge, and was transformed eastward to a spreading center in the Norwegian Basin. By anomaly 6 time (Site 408; Figure 2b), this Norwegian Basin spreading center had become extinct, and a new center developed to the west, which began to separate the Jan Mayen Ridge from east Greenland. Also, near or before anomaly 6 time, Iceland began to appear as a subaerial platform on the Iceland-Faeroe Ridge. Site 336 (Leg 38) on the Iceland-Faeroe Ridge shows biostratigraphy and sedimentology indicating that the site, and probably most of the ridge, was emergent or nearly so up to 30 m.y. ago.

Schrader et al. (1976) believe that the ridge formed a barrier to the southward overflow of Norwegian Sea water until the end of the Miocene. Shor and Poore (this volume) indicate that a lower/middle Miocene unconformity at Site 407 may be correlative with this initiation of overflow. A surface-water connection is estimated from radiolarian faunal similarities to have formed possibly as early as 29 m.y. ago, and definitely by 21 m.y. ago (Schrader et al., 1976).

By anomaly 2' time (Site 409), the present spreading regimes were well established, as was overflow of Norwegian Sea water into the Northeast Atlantic.

\section{Magnetic Anomalies on the Reykjanes Ridge}

The transect of the D/V Glomar Challenger from Scotland to Site 407 enabled us to obtain a long, continuous magnetic and seismic profile across the Reykjanes Ridge. The magnetic anomalies (Figure 3) were identified by application of the sea-floor spreading model (Figure 4). The anomaly identifications are remarkably good and complete for such a slowly spreading ridge. That the Reykjanes Ridge is not highly faulted like other slow-spreading ridges indicates the disruption of magnetic fidelity by this process. At this latitude, the spreading model shows a rate of 0.66 $\mathrm{cm} /$ year before anomaly 6 time, then an abrupt increase to about $0.95 \mathrm{~cm} /$ year after this. This observation conflicts with Vogt and Avery's (1974) interpretation of more monotonic spreading changes on the ridge.

At Site 407 , we drilled into the center of a positive magnetic anomaly (13), but retrieved normally magnetized 


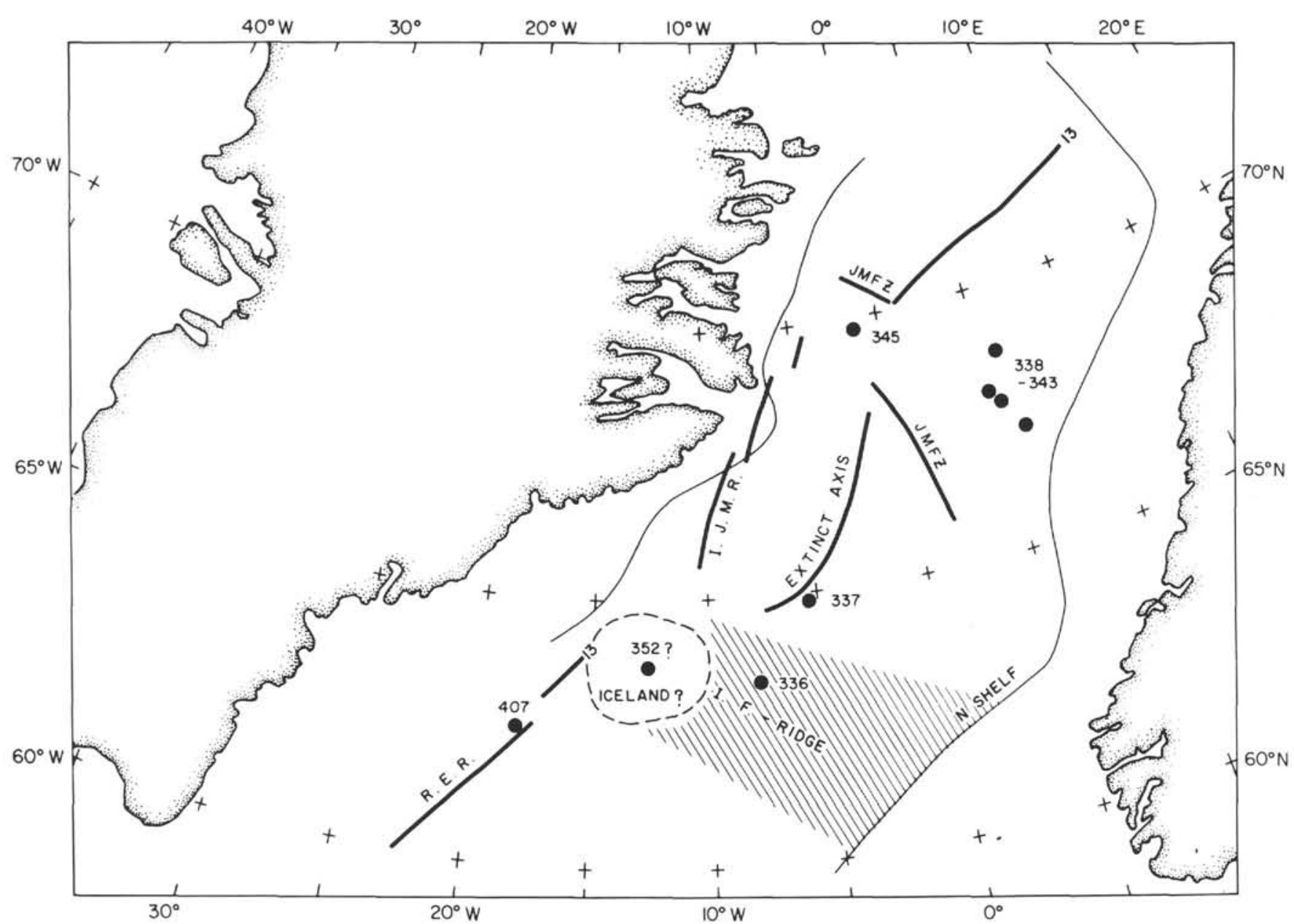

Figure 2a. Reconstruction for anomaly-13 time, showing the relative positions of drill sites and continents. Norway is held fixed. The rotational parameters of Talwani and Eldholm (1977) were used to make the reconstruction. First, Jan Mayen and Sites 346 to 350 , pole $68^{\circ} \mathrm{N}, 137^{\circ} \mathrm{E}, 2.5^{\circ} \mathrm{CW}$; second, Greenland et al., pole $68^{\circ} \mathrm{N}, 130^{\circ} \mathrm{E}, 7.8^{\circ} \mathrm{CCW}$.

basalt overlying reversely magnetized basalt. A possible explanation of this is that the normal interval assigned anomaly 13 has a short reversed event within it. This was first recognized by Heirtzler et al. (1968); so reversely magnetized crust is not unexpected. The observation of normally magnetized crust overlying reversed crust probably results from the configuration of the polarized bodies. Figure 5 shows a crustal magnetization model where the polarity boundaries are arranged according to the model of Kidd (1977). This shows onlap of oppositely magnetized lava flows, which would explain the polarity sequence obtained at Site 407 if the hole was situated as indicated in the figure. An important experiment for the future would be to obtain the actual slope of the normal-reverse interface from a profile of holes.

Evidence indicates that there may have been a hiatus in volcanism at Site 407 , so the contrasting polarities may have been acquired at greatly different times. This hiatus is below the normal-reversed transition in the basement section, however.

\section{The Age-Depth Curve for the Reykjanes Ridge}

Several facts about the topography of the Reykjanes Ridge are very striking. First, the entire ridge is elevated about two kilometers (at $63^{\circ} \mathrm{N}$ ) relative to the normal age-depth curve (Vogt and Avery, 1974; Sclater et al., 1975). Second, the spreading center does not have a rift valley as slow-spreading ridges commonly do (Talwani et al., 1971). Third, abrupt depth changes, in the form of steps, occur in the vicinity of anomalies 6 and $2^{\prime}$ (Figure 6), but appear to be slightly time transgressive so as to be older in the north (Vogt and Avery, 1974).

Vogt and Avery (1974) constructed an age-depth curve for the eastern flank of the ridge by averaging depths over $705 \mathrm{~km}^{2}$ regions. This approach yields a rather smooth increase in depth with time. We have constructed an age-depth plot for the geophysical profile of Figure 3, using magnetic anomaly ages and seismic reflection results (Figure 7). In constructing the plot, we assigned crustal ages at every polarity reversal we could identify. Water depths were determined in corrected meters, and sediment thicknesses were calculated assuming a velocity gradient of $1.0 \mathrm{~s}^{-1}$ and an initial velocity of $1500 \mathrm{~m} / \mathrm{s}$. Basement depths were then isostatically adjusted by removing $1 / 2$ the sediment thickness.

Isostatic basement depths are plotted against (age $)^{1 / 2}$ in Figure 8. Points from both sides of the ridge fall on the contraction slope of $350 \mathrm{~m} /(\mathrm{m} . \mathrm{y} .)^{1 / 2}$ proposed by Parsons 


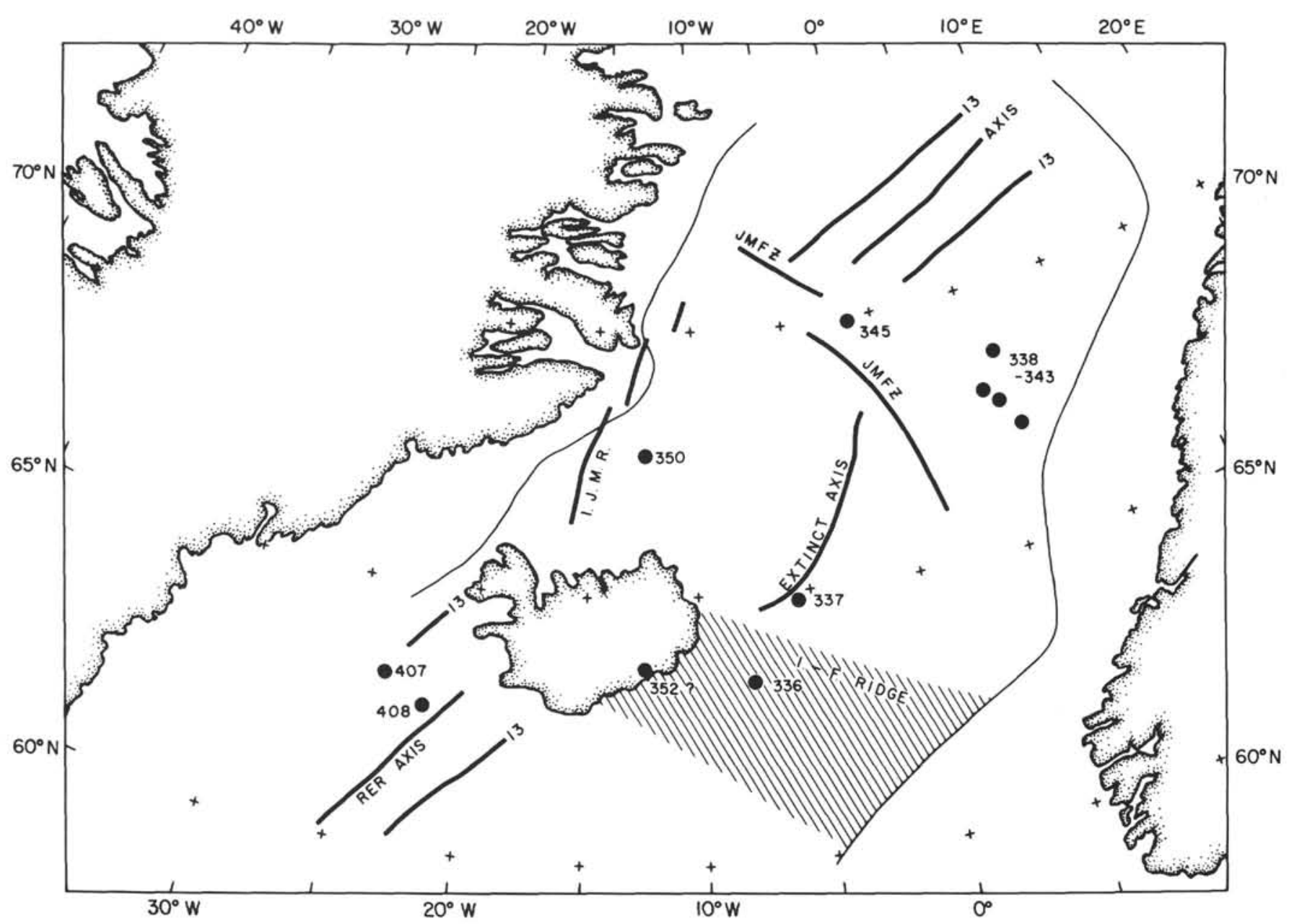

Figure 2b. Reconstruction for anomaly-6 time. Rotational parameters were interpolated from those of Talwani and Eldholm (1977) for anomaly-13 time. First, rotate Jan Mayen et al., as above; second, rotate Greenland et al., pole $68^{\circ} \mathrm{N}, 130^{\circ} \mathrm{E}$, $4.3^{\circ} \mathrm{CCW}$.

and Sclater (1977). Data from both sides also indicate, however, a substantial departure to relatively deeper depths between about 5 and $15 \mathrm{~m} . y$. ago. In fact, it appears that the basement depth was essentially constant during this time span. Does this depth profile represent steady-state behavior, or has the ridge in fact risen and subsided at various times?

If the depth points are backtracked along the 350 $\mathrm{m} /(\mathrm{m} . \mathrm{y} .)^{1 / 2}$ slope, the depth of crustal formation can be determined (Figure 9), assuming that a steady state has persisted. This analysis indicates that the ridge-crest depth has varied with time. This, in turn, shows that the thermal regime underlying the ridge has not remained constant, but has probably been affected by varying sublithosphere temperatures and/or lithosphere thickness. We must therefore look to independent data to determine whether the ridge profile is permanent.

Our drilling results yield two data sets pertinent to this question. The first is a drastic increase in vesicularity in the younger Site 409 compared with Sites 408 and 407 (Duffield, this volume). Volume percentage vesicularity ranges from 38 to 14 at Site 409,15 to 11 per cent at Site 408 , and 7 to 4 per cent at Site 407 . Duffield points out how this cannot be explained by chemical differences, and has determined probable eruptive depths of 500 meters for Site 409, 1400 meters for Site 408, and 2400 meters for Site
407. These depths are not derived from any quantitative interpretation of the vesicularity; rather, the difference between observed depth and theoretical subsidence depth at Site 409 is taken to represent an uplift rate of $52 \mathrm{~m} / \mathrm{m}$.y. Working backward with this assumed uplift rate for 36 million years gives the estimated eruptive depths.

We have estimated depths of eruption by using Duffield's vesicularity data and the depth: vesicularity relationship of Moore and Schilling (1973) for fresh basalt glasses dredged near the axis of Reykjanes Ridge. Moore and Schilling's data are illustrated in Figure 10. An exponential curve fitting these data was derived, and then inverted and used to determine eruptive depths of the Leg 49 samples. The resulting depths are 939 meters (Site 407), 530 meters (Site 408 ), and 210 meters (Site 409). Moore and Schilling's data have a standard deviation of depth \pm 240 meters about the derived curve.

Duffield has objected to use of the Moore and Schilling data; he feels that his samples are biased to high vesicularity since they came from flow interiors, whereas Moore and Schilling's (1973) data pertain to glassy margins. Analyses of the Leg 49 data would therefore yield too shallow eruptive depths.

The second set of independent depth information comes from analysis of benthic foraminiferal assemblages in the basal sediments by William Berggren (Woods Hole 


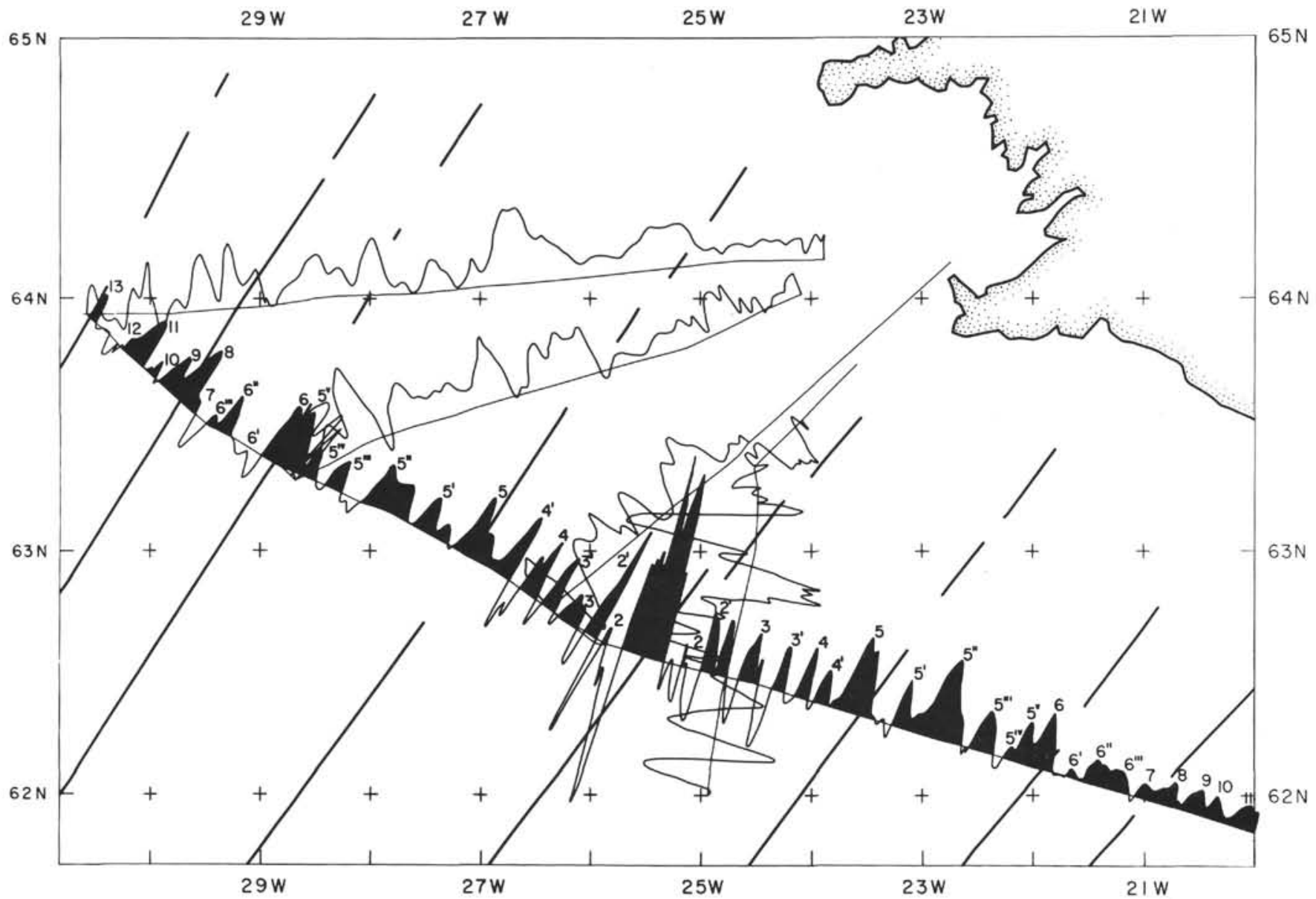

Figure 3. Magnetic anomaly profile across the Reykjanes Ridge taken by the Glomar Challenger on Leg 49.

Oceanographic Institution). The estimates of depositional depth of these samples are $1500 \pm 500$ meters (Site 407), $1000 \pm 200$ meters (Site 408), and $400 \pm 200$ meters (Site $409)^{1}$. Correlative age estimates for thesed samples are $32 \pm 3$ m.y., $17 \pm 1$ m.y., and $2.7 \pm 0.5$ m.y., respectively (Poore et al., this volume and Site Reports). Notice that the analyzed sediments from Sites 407 and 408 are younger than basement age (determined from magnetic anomalies) by several million years.

Both these data sets suggest a net uplift of the Reykjanes Ridge over the past 30 or more million years by 500 to 1000 meters (present crestal depth is $600 \mathrm{~m}$ at this latitude). But, neither data set necessarily represents depths at zero crustal age. In Table 1 we compare the depth determined by the two different observations above, with a calculated depth that assumes subsidence from crestal depths for the period representing the probable age difference between the crust at the site and the sample. In some cases (for example, Site 407 ) the basement samples may be younger than the actual crust (see Site 407 Report). This comparison shows that because of uncertainty in the age differences between the samples and the crust one cannot unequivocally conclude that the Reykjanes Ridge has been uplifted over time:

\footnotetext{
'Berggren (written communication, 1976) analyzed samples from 407 43, CC and 407-36-2; 408-33, CC and 408-34, CC; and 407-7-6.
}

almost all depths fall within the expected ranges. The actual age-depth plot in Figure 8 also supports, on the average, a steady-state profile. Most of the data points fall on the expected subsidence curve and give about the same intercepts (Table 1; Figure 9). The exception is the kink between 15 and 5 m.y.B.P. A steady uplift would manifest itself in Figure 8 by a slope steeper than $350 \mathrm{~m} /(\mathrm{m} . \mathrm{y} .)^{1 / 2}$, and possibly a non-linear plot. As plotted in Figure 8, depth (D) as a function of time is empirically given (e.g., Parsons and Sclater, 1977) as

$$
D(t)=D_{0}+C_{1} t^{1 / 2}
$$

where $C_{1}$ is the contraction coefficient (slope of the curve). A monotonic uplift would appear as

$$
\mathrm{D}(\mathrm{t})=\mathrm{D}_{0}+\mathrm{C}_{1} \mathrm{t}^{1 / 2}+\mathrm{C}_{1}{ }^{\prime} \mathrm{tn}
$$

Because the contraction constant $\left(C_{1}\right)$ is essentially invariant (see below), uplift or subsidence will appear as departures from the square root of age slope.

The problem with the above argument for a steady-state profile is that it assumes the basalt at both Sites 407 and 408 was erupted several million years after formation of the lithosphere it overlies (determined from magnetic anomaly ages). This appears plausible at Site 407 , since sediments were cored after drilling more than 100 meters of basalt (vesicles were counted in samples from the upper basalt unit). There is no independent evidence that basalt at Site 408 was erupted away from the ridge crest. On the other 

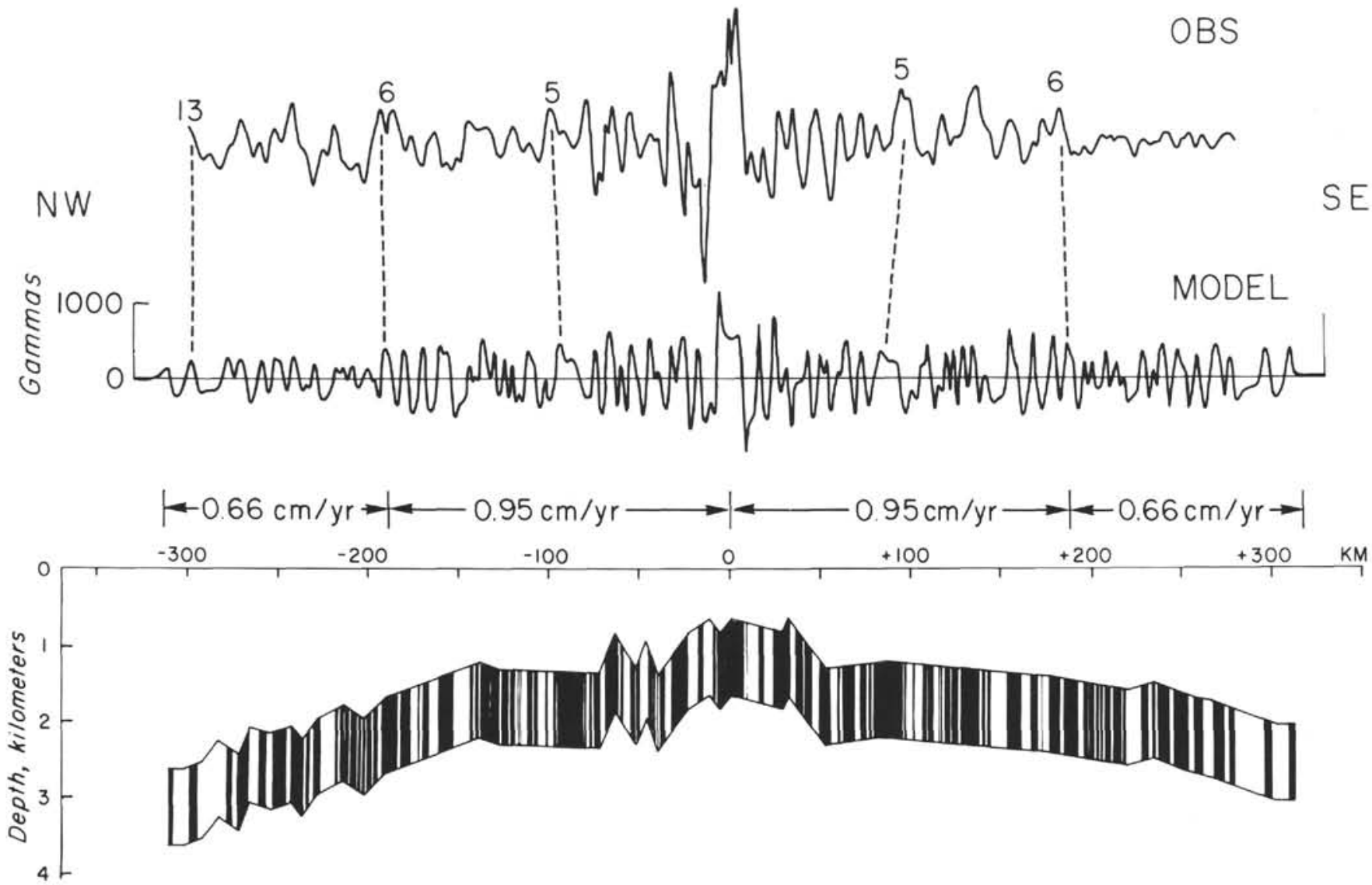

Figure 4. Sea-floor spreading model for the magnetic anomaly profile of Figure 3, using the time scale of La Brecque et al. (1977). The anomaly is calculated for a dipole field with a magnetization of 0.0032 Gauss for the crust, except for the central anomaly, which has a magnetization of +0.007 Gauss. The spreading rate change occurs at 18.9 m.y.

hand, it is fairly certain that the paleontologic samples are younger than the crestal age.

Despite the above discussion, it remains possible that the Reykjanes Ridge has been uplifted over time, either gradually or irregularly. This is obvious if the depths determined by the vesicle and foraminifer analyses represent zero-age crestal depths. In Table 2 we calculated the uplift rates by assuming that they do represent crestal depths, and coupled this assumption with an observed present crestal depth of about 600 meters. A maximum uplift rate of approximately $25 \mathrm{~m} / \mathrm{m}$.y. is indicated by the foraminifer data for Site 407.

It is tempting to speculate on a causal link between any possible uplift of the ridge and the genesis of the Iceland "hot spot," or perhaps even the "bolus" hypothesis of Vogt and Johnson (1973), which suggests that a pulse of mantle plume material propagating southward along Reykjanes Ridge is responsible for the escarpment observed in the vicinity of 150 kilometers from the ridge axis.

Even if the longer term average profile for the Reykjanes Ridge were steady-state, departures from the steady-state age-depth curve suggest episodic uplift and subsidence. A close look at the age-depth plot (Figure 8) shows a steepening of the slope and increase in the intercept elevation near 15 m.y.B.P., a decrease in both parameters between 15 and 4 m.y.B.P., and then a slope and intercept similar to that before $15 \mathrm{~m}$.y.B.P. This can be seen as well in Figure 9, where depths shallower than about 450 meters indicate shallow intercept depths, and deeper depths deeper intercepts. Although they did not indicate it in their age-depth plot, Vogt and Avery (1974) recognized the step-like profile of the Reykjanes Ridge, and related it to increased discharge of the Iceland plume between 18 and 7 m.y. ago (see also Vogt and Johnson, 1973). It is unknown whether this could account for the topographic profile, but we can obtain a gross idea of the thermal behavior of the ridge system by considering a steady-state model in more detail.

Parsons and Sclater (1977) have recently discussed the theoretical steady-state elevation (not depth) of ridges, and give the following expression (their equation 11):

$$
\begin{aligned}
\Delta \rho & =\frac{\rho_{\text {lithosphere }}}{\rho_{\text {lith }}-\rho_{\text {water }}}=1.43 \\
\mathrm{a} & =\text { lithosphere thickness } \\
\mathrm{T}_{1} & =\text { lithosphere bottom boundary temperature } \\
\alpha & =3.1 \times 10^{-5}{ }^{\circ} \mathrm{C}^{-1} \text { (derived) } \\
\mathrm{K} & =8.044 \times 10^{-3} \mathrm{~cm}^{2} / \mathrm{s} .
\end{aligned}
$$



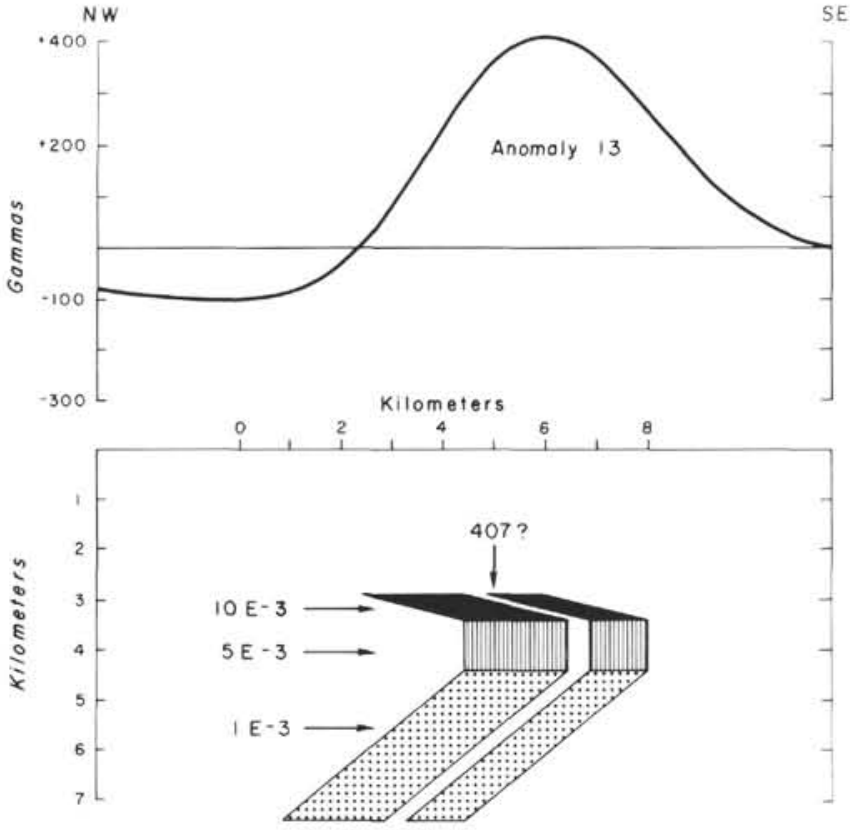

Figure 5. Crustal magnetization model for anomaly 13 at Site 407. The spreading rate is $0.6 \mathrm{~cm} / \mathrm{yr}$ and the time scale of La Brecque et al. (1977) was employed. The polarity boundary shapes are constrained by the model of Kidd (1977). The remanent magnetization is referenced to the spin axis, and the anomaly is referenced to the magnetic dip pole. Black areas are normally magnetized flows, vertical lines are normally magnetized dikes, and large dots are normally magnetized gabbros. Magnetization values are in emu $\mathrm{cm}^{-3}$.

Ocean depth, on the other hand, would be expressed as

$$
D(t)=\left(D_{\infty}-C_{3}\right)+C_{1} t^{1 / 2}
$$

where $\mathrm{D}_{\infty}$ is the asymptotic depth approached for very old (greater than 80 m.y.) lithosphere. Parsons and Sclater give 6400 meters for $\mathrm{D}_{\infty}$; we cannot directly measure this for the Reykjanes Ridge, but by accounting for a positive depth anomaly of 2000 meters (Vogt and Avery, 1974; see also Figure 7), we can estimate it as 4400 meters.

Inspection of Equation 3 shows that the slope of the age-depth curve $\left(\mathrm{C}_{1}\right)$ may depend primarily on the sublithosphere temperature $\left(\mathrm{T}_{1}\right)$. The intercept $\left(\mathrm{C}_{3}\right)$ apparently depends on the product of this temperature and the lithosphere thickness. The intercept $\left(\mathrm{C}_{3}\right)$ cannot be determined directly from a plot such as Figure 8. From Equation $4, C_{3}=D_{\infty}-D(0)$. Therefore, even through $D(0)$ is 2000 meters less than normal for the Reykjanes Ridge, the relief (which is $\mathrm{C}_{3}$ ) may be the same as for normal ridges if $\mathrm{D}_{\alpha}$ has thenormal value of $\mathrm{D}(0)+3900$ meters (Parsons and Sclater, 1977). We cannot evaluate this parameter for the Reykjanes Ridge.

What can the kinks in the profile of Figure 8 tell us about the thermal model for the Reykjanes Ridge? At the very least, changes in the slope and intercept must be related to changes in $T_{1}$. According to the steady-state model, the changes in the plot may be taken as indicators of change in the sub-lithosphere temperature (assuming no change in physical properties of the lithosphere). With reference to the sublithosphere temperature prior to $15 \mathrm{~m}$.y.B.P., the temperature increased during the period from 15 to $13 \mathrm{~m} . \mathrm{y}$. B.P., decreased from 13 m.y.B.P. to 4 m.y.B.P., and increased back to its initial value at 4 m.y.B.P. Application of steady-state models to the data may, however, be invalid. A proper thermal model for the Reykjanes Ridge must take into account $T_{1}$ as a function of time and variation in asthenosphere density, both of which may vary in space and time (e.g., Vogt and Johnson, 1973).

Notice again that Equation 3 cannot explain the net elevation anomaly of the Reykjanes Ridge unless $D_{\infty}$ - and therefore relief $\left(\mathrm{C}_{3}\right)-$ can be determined. If $\mathrm{D}_{\alpha}$ were less than the normal value of 6400 meters, then the depth anomaly might be attributed to lithosphere thinning.

Detrick and Crough (in press) have pointed out the possible role of lithosphere thinning in lithosphere uplift. If the lithosphere/asthenosphere boundary rises, through mantle heating for example, then isostatic compensation will require that the lithosphere rise. This seems a more realistic model for what may be occurring under the Reykjanes Ridge. A simple isostatic calculation shows that a plate uplift of 2 kilometers can be accounted for by lithosphere thinning from 100 kilometers to 47 kilometers, when compensation is taken to be below the lithosphere $\left(\rho_{\text {lith }}=3.33 ; \rho_{\text {asth }}=3.23 ; \rho_{\text {water }}=1.0\right)$. Although this idea may work for the ridge flanks, it cannot work at the crest, where the lithosphere thickness is zero. Here, uplift could result from a decrease in asthenosphere density, caused by an increase in asthenosphere temperatures.

Contrasting with these ideas, Sclater et al. (1975) have shown a positive correlation between gravity anomalies and topographic anomalies in the North Atlantic, including the Reykjanes Ridge. They attribute the residual elevation anomalies to dynamic uplift by mantle convection.

To summarize, it appears that the drilling data do not allow resolution of the age of the Reykjanes Ridge anomaly; nor do they tell whether the ridge profile has been steady state since the anomaly originated. The results from drilling Site 336 ( 30 m.y.B.P.) on the Iceland-Faeroes Ridge show that this site was exposed subaerially (Talwani and Udintsev, 1976). The depth anomaly therefore probably existed $30 \mathrm{~m} . y$. ago, if not $36 \mathrm{~m} . \mathrm{y}$. ago (Site 407). Other evidence of uplift might be found in the geology of the adjacent continents, since they were close to the spreading axis during this period.

The geochemistry of the basalts had been expected to indicate whether a topographic anomaly existed for the Reykjanes Ridge at the time the crust at Site 407 was formed. But after a detailed survey of the analytical data from Leg 49 and from other sources, Wood et al. (this volume) and Tarney et al. (this volume) conclude that the geochemistry does not clearly relate to this question. The wide range of basalt compositions at each site suggests that there is no straightforward correlation of geochemistry with topographic anomaly, or even with the presence of a topographic anomaly. The lavas from Site 410 have a composition which could be interpreted as indicating a closer approach to a "plume" than those on the Reykjanes Ridge. Yet there is no topographic anomaly at Site 410 $\left(45^{\circ} \mathrm{N}\right)$ to compare with that near Iceland. The geochemistry does, however, show that the crust at all three Reykjanes Ridge sites was produced from mantle of very consistent 


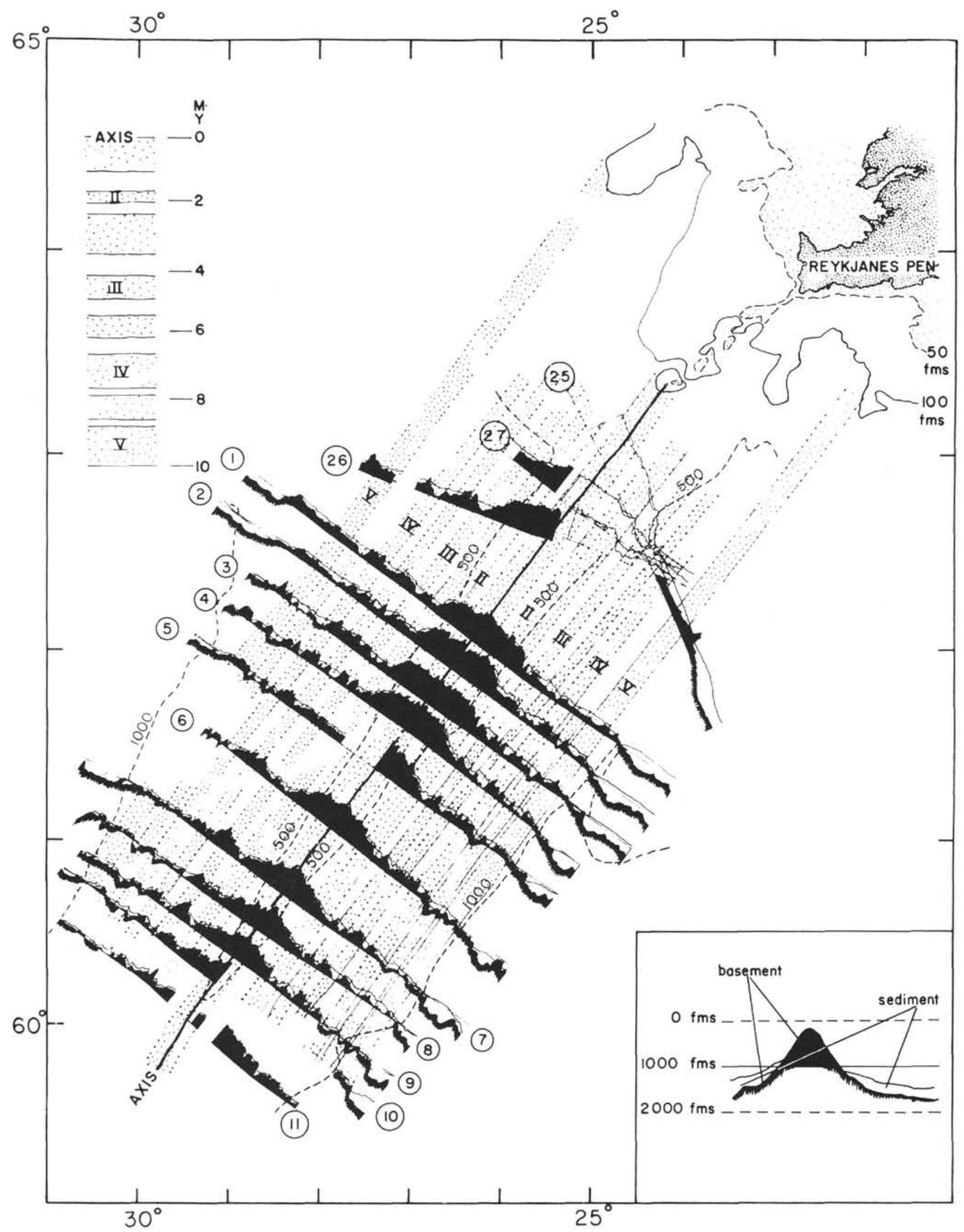

Figure 6. Topographic sections across the Reykjanes Ridge, from Talwani et al. (1971). 


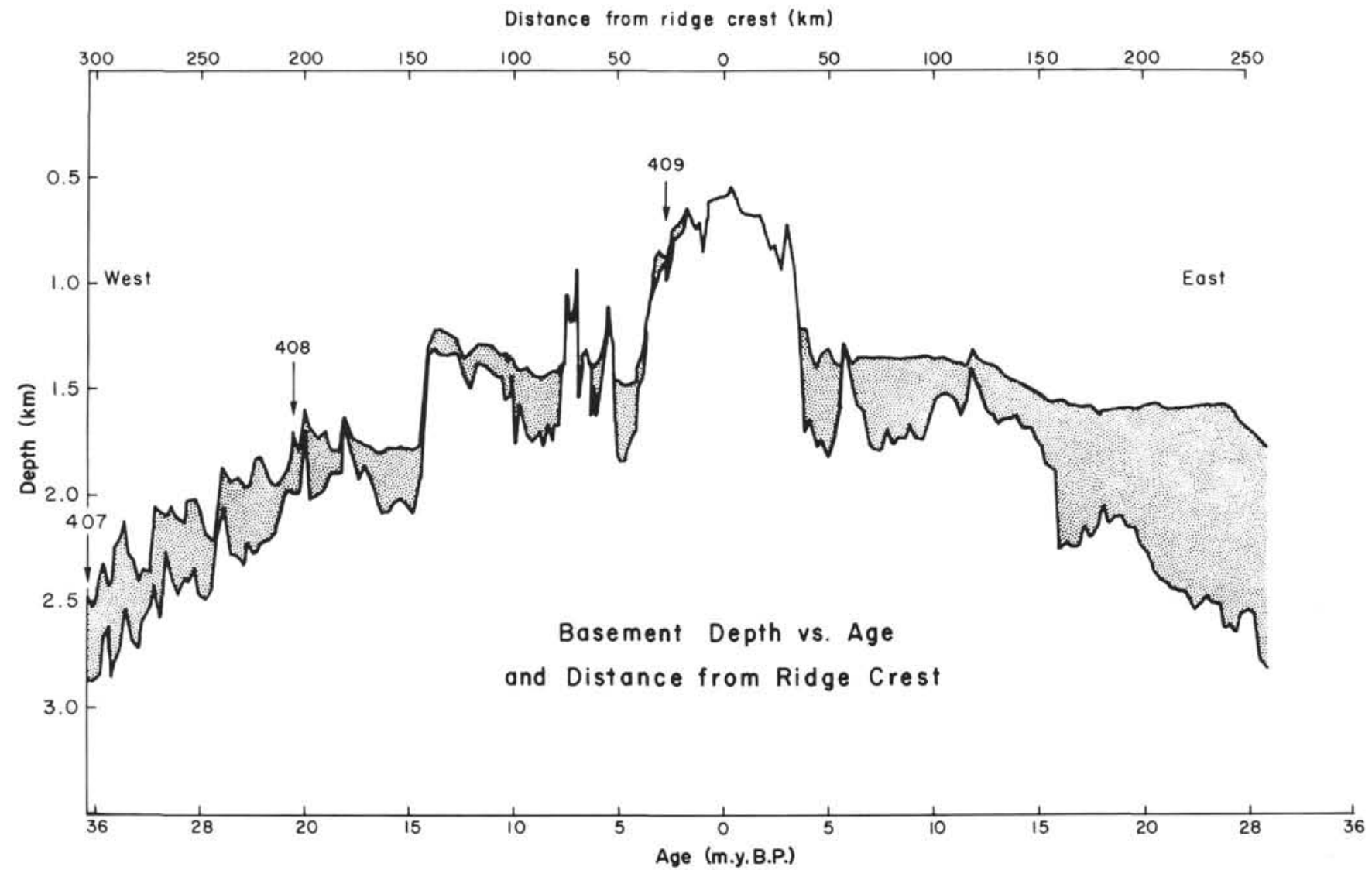

Figure 7. Line drawing interpretation of a seismic profile across the Reykjanes Ridge (location in Figure 3).

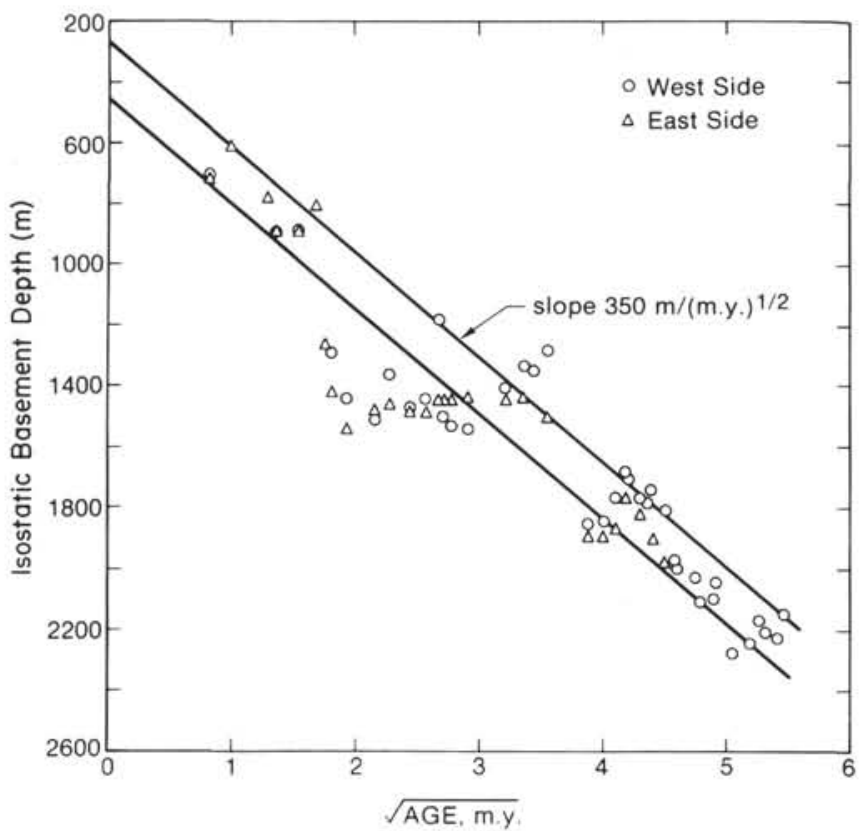

Figure 8. Age-depth plot across the Reykjanes Ridge from the data shown in Figures 3 and 7. See text for explanation.

composition (Cann et al., this volume), and would seem to preclude any solution to the problem that involves a sudden change in the character of the mantle at any time since formation of Site 407 basalts.

\section{DRILLING INTO BASEMENT NEAR SPREADING CENTERS (HOLES 409, 410, 410A, 411)}

Sites 409,410 , and 411 included holes drilled into relatively young basement. The youngest is at Site 411 (about 1 m.y.); basement at Site 409 (about 2.4 m.y.) and at Site 410 (about 9 m.y.) is successively older (Figure 11). The geochemical results from these sites are of prime importance, and are discussed by Wood et al. (this volume), Tarney et al. (this volume), and Cann et al. (this volume). Here we summarize some of the more general observations.

\section{Basement Lithology and Structure}

The gross basement characteristics of these three sites contrast sharply with one another. At Site 411, about fifteen massive fine-grained basalt flows, averaging 3 to 4 meters thick, were drilled. These basalts are dense and not highly vesicular. They also fracture readily (or were previously fractured), which made drilling extremely difficult. No calcite veining, which seems to hold together basement rocks in older crust, is present. The upper flows here are olivine phyric pillow basalts; flows lower in the section are more massive, coarser grained, and plagioclase phyric. This petrologic contrast correlates with differences in geochemistry.

The record single-bit penetration at Site 409 (239 m) can be attributed to the high vesicular nature of the basalts here (14 to $38 \%$ ), probably a consequence of the shallow eruptive depths. The basement drilled here is believed to be composed entirely of pillow lavas with either minor or no 


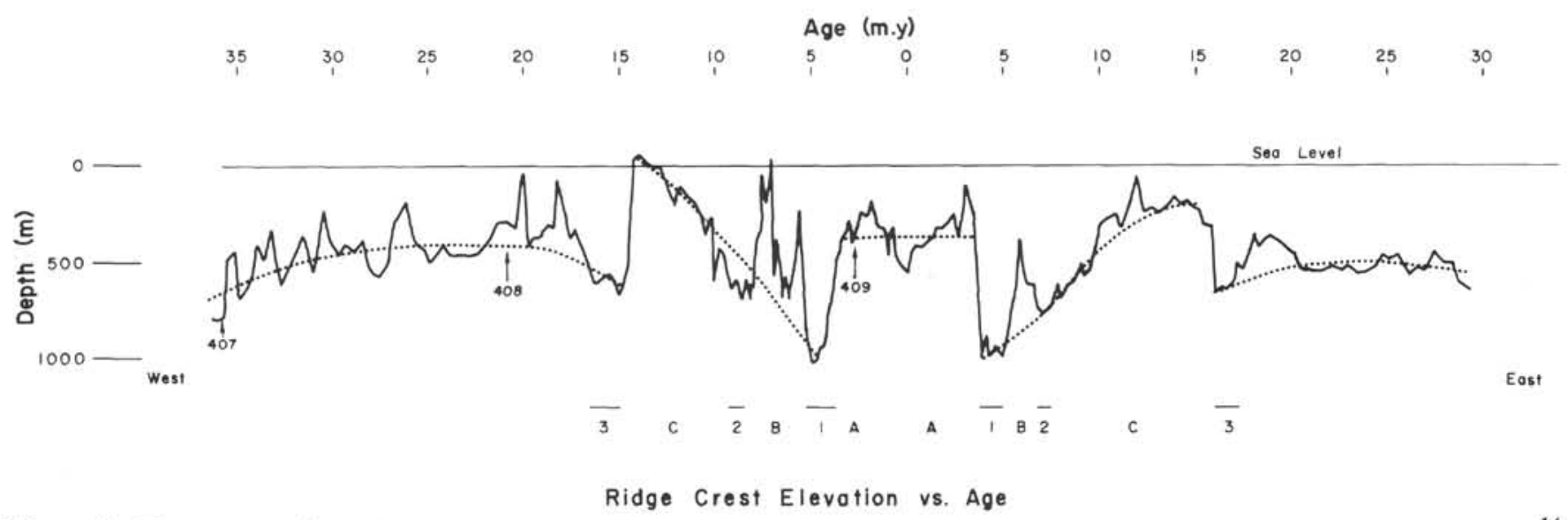

Figure 9. Time series of initial ridge-crest depths, determined by backtracking basement depths $($ Figure 8$)$ along $\Delta z=350(t)^{1 / 2}$ (Parsons and Sclater, 1977)' Mean ridge crest depths ( \pm standard deviation) for the east and west limbs, respectively, are $473 \pm 203$ and $440 \pm 220$ meters. Dotted line is an "eyeballed" curve representing possible average behavior with time.

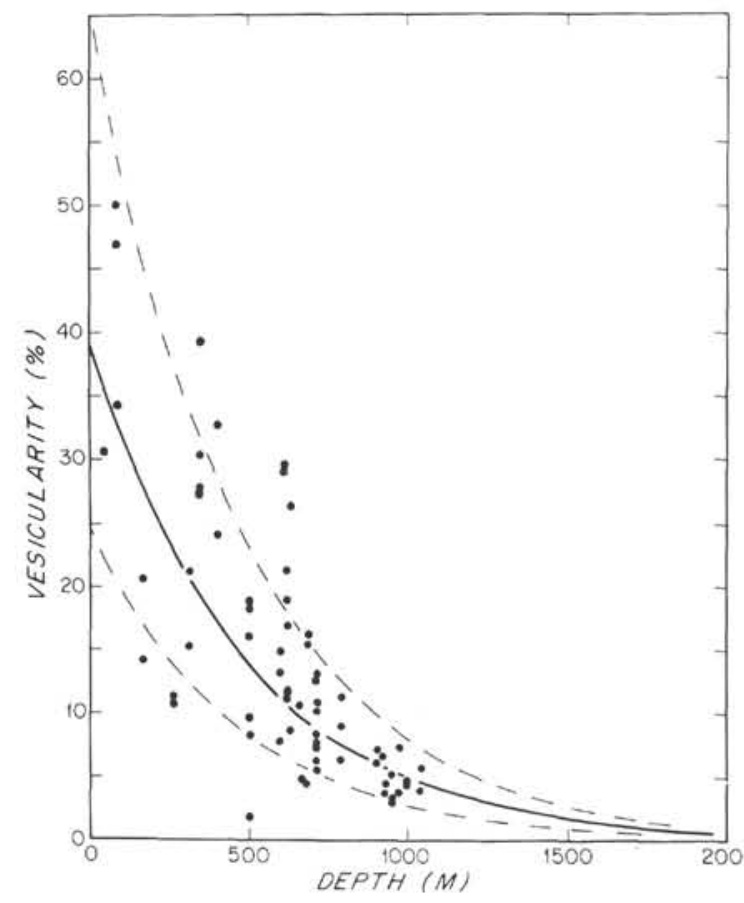

Figure 10. Vesicularity $(\%)$ versus depth $(m)$ for Reykjanes Ridge crest basalts (from Moore and Schilling, 1973).

Data are fitted to exponential $v=40 e^{-.002085 z}$ with correlation coefficient $r=0.73$. Inverse curve $z=1770$ - $480(\ln v)$ is used to predict eruption depths of Leg 49 samples analyzed by Duffield (this volume). Standard deviation of observed depths from calculated depths is 240 meters.

components of massive basalts. About 58 flows, averaging 3 to 4 meters thick, were drilled, and 23 glassy zones were recognized. The basalt is largely aphyric to sparsely phyric. These latter are olivine tholeiites, olivine-plagioclase basalts, or more evolved basalts. Only four geochemical units were recognized, and neither the petrology nor chemistry indicate magmatic evolution over time although different primary magmas are suspected.

The contrasts between basement rocks at Holes 410 and $410 \mathrm{~A}$ stress the variability to be expected when drilling into the upper ocean crust. Hole 410 basement rocks consist of about 40 meters of pillow basalt-limestone breccia which is more compact at the base. The section can be divided into two petrologic and geochemical units. There is evidence that the basalt was emplaced into overlying limestone while it was solid, but also within the range of magmatic blocking temperatures. The basement at Hole $410 \mathrm{~A}$ has very little interlayered sediment and is vesicular pillow lava (up to $25 \%$ vesicles). Two geochemical units and seven petrologic or flow units were recognized. Both Holes 410 and $410 \mathrm{~A}$ bottomed in a layer of basalt glass sand.

Except for the high vesicularity in the Site 409 rocks, none of the contrasts in the basement structure at these sites seem to be related to special tectonic settings or processes. An important observation is that flow thicknesses and types, petrology, and geochemistry variations do not seem correlated in any obvious way. The drilling logs from all sites indicate high percentages of easily drilled zones which may be basalt rubble or sediments, but which were not recovered. Rubbly or sediment zones may demarcate seismic Layer 2A from Layer 2B below. Sonic velocity measurements on basalt samples clearly show a higher velocity range for younger rocks: Hole 411 rocks, 5 to 6 $\mathrm{km} / \mathrm{s}$; Hole $409,3.7$ to $5.7 \mathrm{~km} / \mathrm{s}$; Hole $410 \mathrm{~A}, 3.9$ to 4.3 $\mathrm{km} / \mathrm{s}$. This trend may or may not be statistically significant.

\section{Alteration of Basement Rocks}

The basalts from Hole 411 are the least altered. In fact, these rocks generally show none of the usual alteration products, except for very minor smectite in a few vesicles. Carbonate and zeolite minerals are notably absent. The rocks at Hole 409 are also very fresh, and show no replacements of olivine or alteration of glass. Zeolite minerals are also absent, but aragonite and some clay minerals occur in the vesicles. In some places, the aragonite is common and abundant. The basalts from Holes 410 and $410 \mathrm{~A}$ show more alteration; there is some olivine replacement and palagonitization of glass. The holocrystalline basalt recovered here is the freshest. Zeolites and calcite are present in the vesicles of Hole 410. In Hole $410 \mathrm{~A}$, alteration is very slight in the top and bottom of the lava section, but the middle section is highly altered and 
TABLE 1

Test of the Hypothesis That the Reykjanes Ridge Age-Depth Profile is Steady-State

\begin{tabular}{lccccc}
\hline \multicolumn{1}{c}{ Data and Method } & Site & $\begin{array}{c}\text { Paleodepth } \\
(\mathrm{m})\end{array}$ & $\begin{array}{c}\text { Relative } \\
\text { Age for } \\
\text { Paleodepth } \\
\text { (m.y.) }\end{array}$ & $\begin{array}{c}\text { Expected Steady-State } \\
\text { Paleodepth at Paleodepth } \\
\text { Age for } \mathrm{D}_{\mathrm{O}}=450 \pm 210^{\mathrm{a}}(\mathrm{m})\end{array}$ & Agreement? \\
\hline Vesicle percentage & 407 & $939 \pm 240^{\mathrm{b}}$ & $0-6$ & $450-1310$ & OK \\
& 408 & $530 \pm 240$ & $0-3$ & $450-1056$ & OK \\
Benthic foraminifers & 409 & $210 \pm 240$ & 0 & $450 \pm 210$ & OK? \\
& 407 & $1500 \pm 500$ & $1-6$ & $800-1310$ & OK? \\
Backtracking to & 408 & $1000 \pm 200$ & 3 & 1056 & OK \\
magnetic anomaly age & 409 & $400 \pm 200$ & 0 & 450 & OK? \\
& 408 & 270 & 0 & $450 \pm 210$ & OK? \\
\hline
\end{tabular}

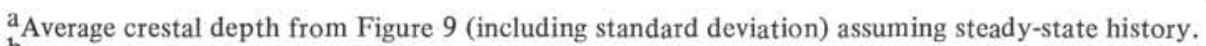

${ }^{b}$ Standard deviation of data of Moore and Schilling (1973).

TABLE 2

Maximum Uplift Rates Indicated by Vesicularity and Paleontological Data ${ }^{a}$

\begin{tabular}{lcccc}
\hline \multicolumn{1}{c}{ Method } & Site & $\begin{array}{c}\text { Assumed } \\
\text { Crestal Depth (m) }\end{array}$ & $\begin{array}{c}\text { Age } \\
\text { (m.y.) }\end{array}$ & $\begin{array}{c}\text { Uplift } \\
\text { Rate } \\
(\mathrm{m} / \mathrm{m} . \mathrm{y} .)\end{array}$ \\
\hline Vesicularity & 407 & 939 & 36 & 9.4 \\
& 408 & 530 & 20 & $\ldots .$. \\
Benthic foraminifers & 409 & 210 & 2.4 & $\ldots$ \\
& 407 & 1500 & 36 & 25 \\
& 408 & 1000 & 20 & 20 \\
& 409 & 400 & 2.4 & $\ldots$ \\
\hline
\end{tabular}

${ }^{a}$ Present crest depth taken as 600 meters.

${ }^{b}$ Paleodepths in Table 1 assumed to be depths of origin (crestal depths),

smectite is abundant. The calcareous sediments in Hole 410 do show some evidence of reducing conditions followed by oxidation; this may be related to hydrothermal activity. The upper 200 meters of the 340-meter sediment section shows clear evidence of sulfate reduction. Below 200 meters, it appears that secondary oxidation has taken place; in fact, the 50 meters of sediment above basement is yellowish, and contains oxidized pyrite and marcasite concretions (see discussion in Site 410 Report: Geochemistry).

The degree of alteration of the basalts is closely related to the age of the crust. The older crust is much more altered than the young crust (Floyd and Tarney, this volume). This strongly suggests that most of the alteration was not hydrothermal, but the result of prolonged reaction between basalt and cold sea water. The rocks of Site 408 , which are much more altered than would be expected from their age alone, are a possible exception, but no clearly high temperature effects are evident in them.

\section{Magnetic Properties}

A fairly complete set of magnetic experiments was performed on all basement rocks. These are discussed by Steiner et al., Day et al., and Luyendyk, in this volume. The NRM (natural remanent magnetism) values for samples from Holes 411, 409, 410, and 410A are generally similar: in the range of 2 to $6 \times 10^{-3} \mathrm{emu} \mathrm{cm}^{-3}$. This is a typical value for DSDP basalts, and suggests that marine magnetic anomalies originate from the upper kilometer or more of Layer 2. Two very distinct magnetic types occur. Type I is a slightly oxidized basalt with a reversible thermomagnetic curve, and Type II has highly oxidized (low temperature) magnetic grains and an irreversible curve. Both types are present in Holes 411 and 409, but Holes 410 and 410A contain almost solely the highly oxidized variety of titanomagnemite. Other contrasts in magnetic properties are a finer grain size (SD to PSD), a higher coercive force $(>100$ Oe), a higher Curie temperature, and a lower susceptibility for the more oxidized samples (Table 3 ). It is not possible to resolve whether the oxidation reduces the grain size or the smaller grains are more readily oxidized (Day et al., this volume).

The consistent oxidized character of the Site 410 rocks may be correlated with more intense alteration of these basalts compared with those at Sites 411 and 409. Again, an aging effect is suggested, but not proved with so few data points.

Inclination data were examined by Luyendyk (this volume) to determine paleocolatitudes. Because the sites we drilled were not thought to have changed latitude significantly, the paleocolatitudes from the basalts should agree with the present colatitudes. Recovery at Site 411 was insufficient to statistically determine a paleocolatitude, but Holes 409 and 410A showed much higher colatitudes than expected (Figure 12). This effect may be a result of tectonic tilting, demagnetization effects in massive lava flows, or secular variation. Hole $410 \mathrm{~A}$ inclinations show a steady decrease with depth. This could suggest a continual tectonic tilt as the lavas accumulated. The inclination discrepancy is extreme, however - a tilt of 71 degrees westward about the Mid-Atlantic Ridge strike is required to reconcile the data with the expected colatitude.

The magnetic inclination data also allow definition of magnetic cooling units, lava sequences which erupted during a short enough period that secular variation is not evident in the magnetic directions. Generally, the magnetic cooling units encompass several flows (flow units) as well as units of varying petrology (petrologic units). On the other hand, the magnetic cooling units coincide in some instances with geochemical units (Holes 407, 408, 410?, 410A; see 


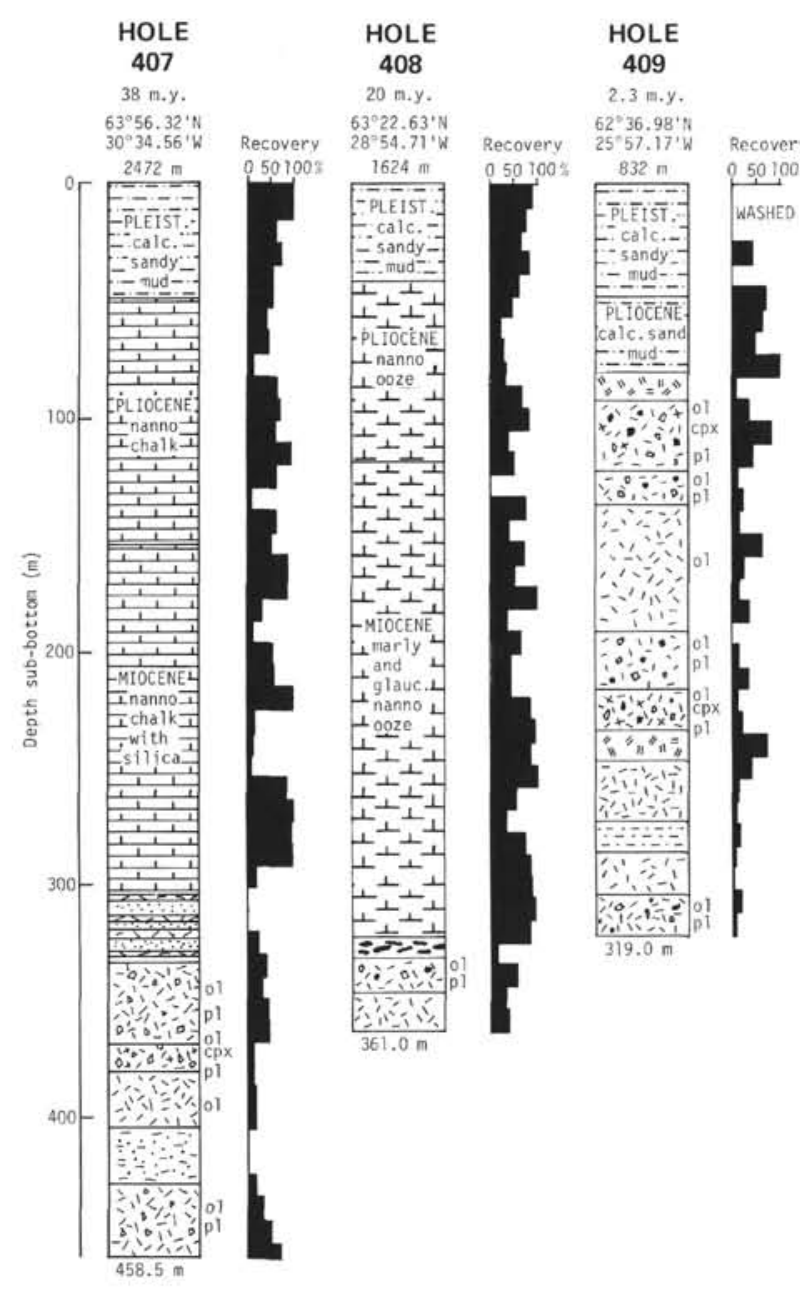

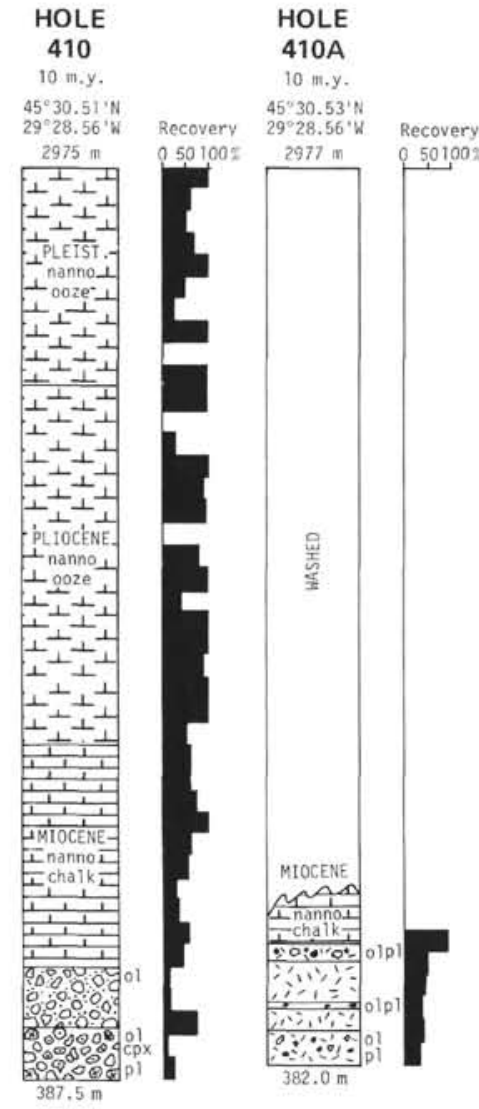

gog weathered basalt (boulders)

F:D.: hydoclastite or volcanic clay

interlayered sedinent

$\nabla$ foult
HOLES HOLE HOLE

$\begin{array}{llll}411,411 \mathrm{~A} & 412 & 412 \mathrm{~A} & 413\end{array}$

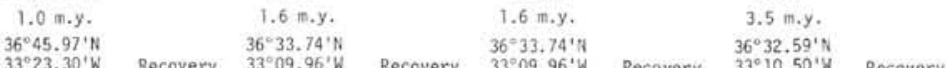
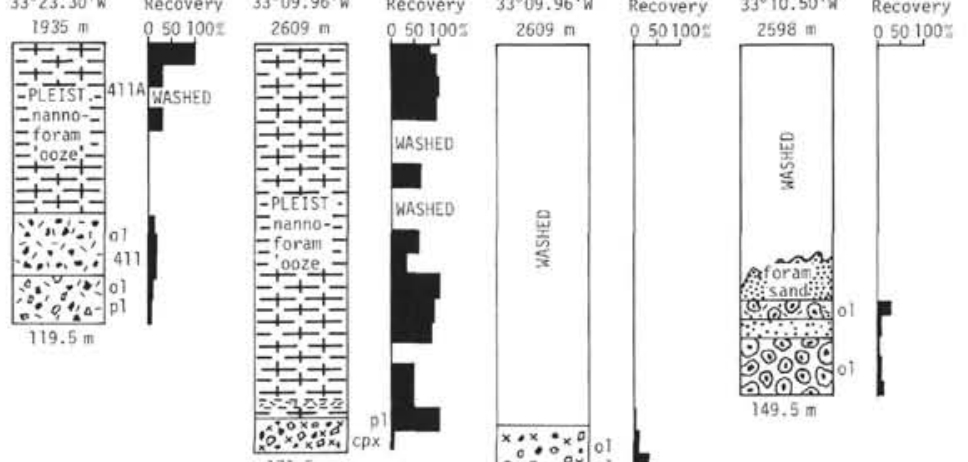

Leq 49:

- 294.0 ma (simplified section: not

aphyric basalt and olivine sparsely
phyric (ol) - flows or pillows

Did olivine-plagioclase sparsely

Dativine porphyritic (5-155) basalt

olfvine-plagioclase-clinopyroxene porphyritic

$\hat{N}=0$ evolved basalt (basaltic or tholeifitic andesite)

$E=$ compacted hyaloclastite

8"id breccia with 1 imestone and hyaloclastite cenent

영 brecciated pillow

Figure 11. Stratigraphic sections drilled on Leg 49. 
TABLE 3

Representative Magnetic Properties of Leg 49 Basalts

\begin{tabular}{|c|c|c|c|c|c|c|c|c|c|c|}
\hline & ${ }^{T} C^{a}$ & $\mathrm{~J}_{\mathrm{S}}^{\mathrm{b}}$ & ${ }^{\mathrm{J}_{\mathrm{RS}}} /_{\mathrm{J}} \mathrm{S}$ & $\mathrm{H}_{\mathrm{C}}{ }^{\mathrm{c}}$ & $\mathrm{H}_{\mathrm{RC}}{ }^{\mathrm{d}}$ & ${ }_{\mathrm{RC}} /_{\mathrm{H}_{\mathrm{C}}}$ & $\mathrm{x}^{\mathrm{e}}$ & $\mathrm{J}_{\mathrm{RS}}{ }^{\mathrm{f}}$ & $\mathrm{J}^{\mathrm{g}}$ & $Q^{h}$ \\
\hline \multicolumn{11}{|c|}{ Reversible (type I) } \\
\hline $\begin{array}{l}\text { Mean } \\
\text { Minimum } \\
\text { Maximum }\end{array}$ & $\begin{array}{l}197 \\
143 \\
270\end{array}$ & $\begin{array}{l}2.04 \\
1.08 \\
3.70\end{array}$ & $\begin{array}{l}0.15 \\
0.03 \\
0.28\end{array}$ & $\begin{array}{l}50 \\
17 \\
90\end{array}$ & $\begin{array}{r}106 \\
70 \\
182\end{array}$ & $\begin{array}{l}2.41 \\
1.59 \\
4.17\end{array}$ & $\begin{array}{l}2.01 \\
1.1 \\
3.13\end{array}$ & $\begin{array}{l}0.285 \\
0.109 \\
0.748\end{array}$ & $\begin{array}{c}4.29 \\
0.79 \\
12.9\end{array}$ & $\begin{array}{c}5.7 \\
0.83 \\
14.0\end{array}$ \\
\hline \multicolumn{11}{|c|}{ Irreversible (type II) } \\
\hline $\begin{array}{l}\text { Mean } \\
\text { Minimum } \\
\text { Maximum }\end{array}$ & $\begin{array}{l}286 \\
208 \\
405\end{array}$ & $\begin{array}{l}0.678 \\
0.284 \\
1.22\end{array}$ & $\begin{array}{l}0.49 \\
0.34 \\
0.68\end{array}$ & $\begin{array}{l}241 \\
110 \\
506\end{array}$ & $\begin{array}{l}350 \\
166 \\
655\end{array}$ & $\begin{array}{l}1.49 \\
1.29 \\
1.75\end{array}$ & $\begin{array}{l}0.348 \\
0.193 \\
0.616\end{array}$ & $\begin{array}{l}0.305 \\
0.160 \\
0.540\end{array}$ & $\begin{array}{l}4.4 \\
1.30 \\
12.3\end{array}$ & $\begin{array}{l}27.5 \\
10.4 \\
88.0\end{array}$ \\
\hline
\end{tabular}

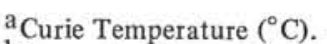

${ }^{\mathrm{b}}$ Saturation Magnetization $\left(\mathrm{emu} \mathrm{cm}^{-3}\right)$.

Coercive Force (Oe).

$\mathrm{d}$ Remanent Coercive Force (Oe).

Initial Susceptibility $\left(\times 10^{-3}\right.$ emu cm $\left.\mathrm{cm}^{-3} \mathrm{Oe}^{-1}\right)$.

${ }^{f}$ Saturation Remanence $\left(\mathrm{emu} \mathrm{cm}^{-3}\right)$.

Intensity of Natural Remanent Magnetization $\left(\times 10^{-3} \mathrm{emu} \mathrm{cm}^{-3}\right)$.

${ }^{\text {Koenigsberger Ratio. }}$

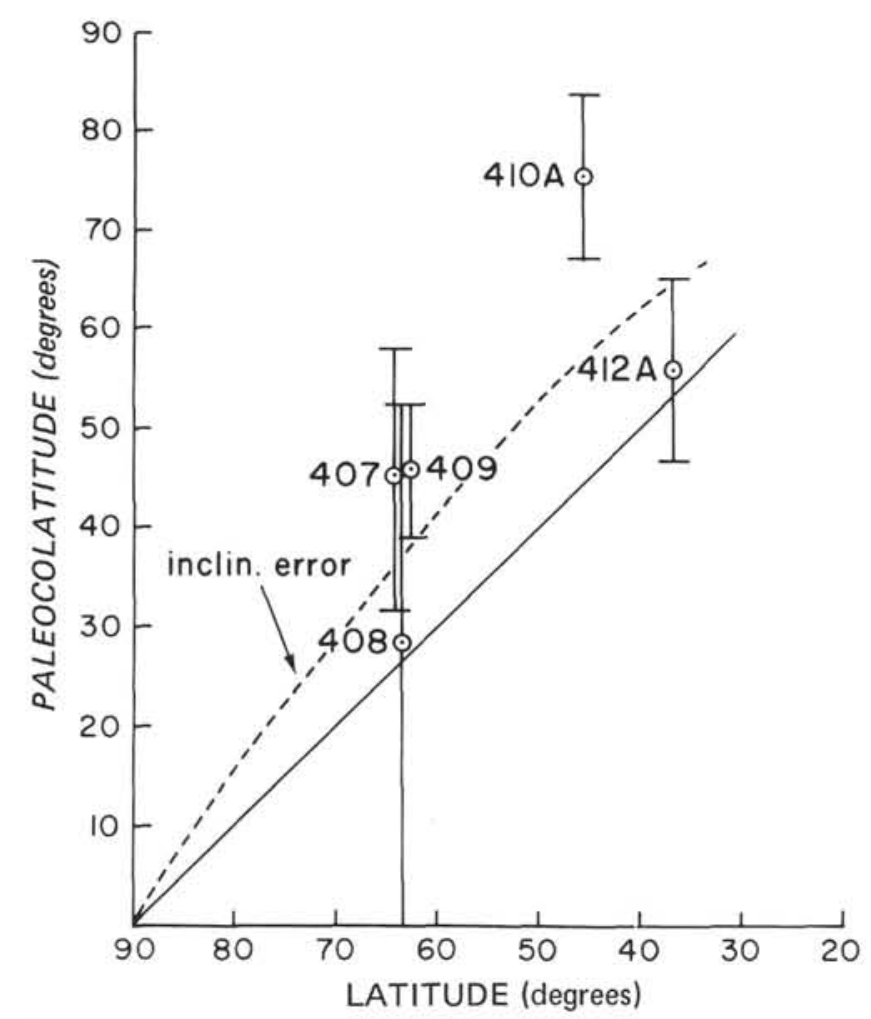

Figure 12. Measured paleocolatitudes (determined from magnetic cooling units) plotted against site latitude. The straight line is the expected result for no latitudinal motion; error bars are 95 per cent confidence limits; dashed line is expected result from an inclination error due to highly magnetized sheet-like lava flows. From Luyendyk, (this volume).

Wood et al., Steiner et al., and Luyendyk, this volume). At Hole $412 \mathrm{~A}$, the small variation in geochemistry and in magnetic inclination made it difficult to distinguish either type of unit. It appears at first glance, then, that geochemical variations occur on the same time scale as magnetic variation $\left(10^{3}\right.$ to $10^{4}$ years), but that volcanic activity and petrology vary more rapidly.

\section{DRILLING IN FRACTURE ZONE $B$ (SITES 412 AND 413)}

Three holes were drilled at two sites in fracture zone $B$, FAMOUS Area (Figure 13). The geology of fracture zones like those in the Atlantic has received special study by investigators too numerous to review here. Most of their studies were made with conventional survey methods and dredging. Fracture zone $A$ at $37^{\circ} \mathrm{N}$ was the locale of a deep-tow instrument survey (Detrick et al., 1973) and French submersible operations during Project FAMOUS (ARCYANA, 1975). The FAMOUS rift valley and fracture zone $B$ were mapped with narrow-beam sonar and seismic reflection (Phillips and Fleming, unpublished) and by the GLORIA long-range side-scan sonar (Whitmarsh and Laughton, 1976). We would have preferred to locate our sites in fracture zone $A$ to compliment the very detailed observations here, but sufficient sediment section for spud-in was not available there.

We were interested in drilling in a fracture zone for several reasons. For one, fracture zones are usually considered anomalous regions of the ocean crust, because it is from them that many exotic rock types are recovered (e.g., Fox et al., 1976). Because all rock samples from fracture zones are obtained by dredging, and are thus poorly located, deep drilling could provide valuable stratigraphic information. Also, it has long been speculated that hypothermal activity occurs preferentially in fracture zones; in fact, ARCYANA (1975) found direct evidence of activity in fracture zone $A$. A third objective was to drill into young ocean crust - anomalous or not. Fracture zone valleys provide a focal point for sedimentation, so in some places sufficient sediment cover exists over young crust to spud-in; the cover is a hundred meters thick at Sites 412 and 413 (Figure 10). 


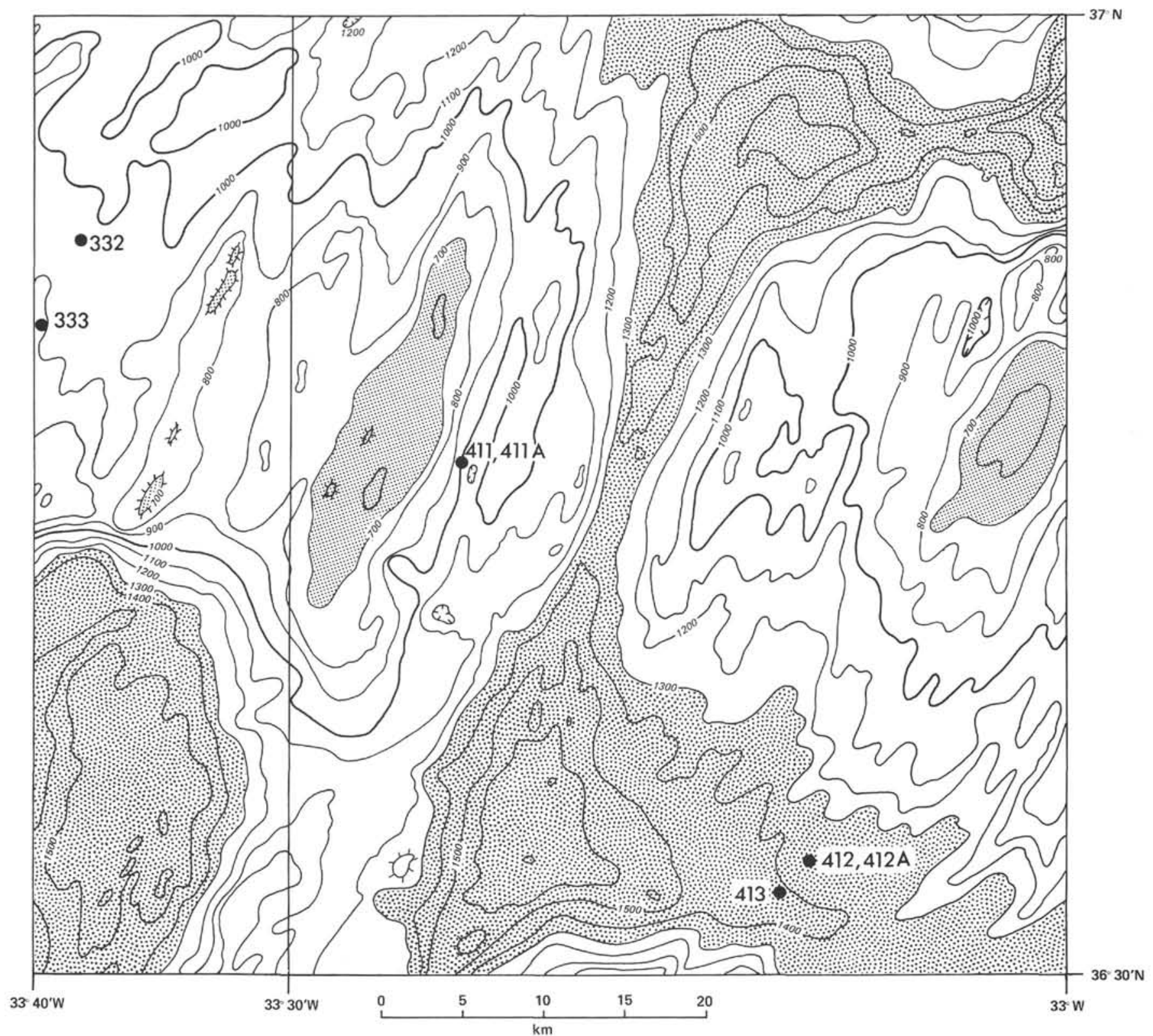

Figure 13. Topographic chart of the FAMOUS area, including the western portion of fracture zone B and showing the locations of Sites 412 and 413. Contours in uncorrected fathoms after Phillips and Fleming (unpublished).

Site 412 is along strike from anomaly 2 (1.6 m.y.), in the rift mountains to the north. The sediment section here is no older than lower Pleistocene (NN 19), which suggests that this crust originated from the northern spreading center. In Hole $412 \mathrm{~A}, 131$ meters of basalt was penetrated, including 26 or 27 flows. Basalt in the upper 50 meters is olivine, plagioclase, and clinopyroxene phyric. The clinopyroxene phenocrysts are a striking emerald green. The lava pile is fresh and free of alteration products. Calcite and zeolite vein material are rare. The sedimentary section, by contrast, shows an alteration history very similar to that at Hole 410 : the entire sediment section was subjected to reducing conditions, with resulting formation of pyrite, and then the lowermost section was oxidized. As at Hole 410, this could suggest hydrothermal oxidation, but evidence for this in the basalt is not clear.
Finely bedded limestone was recovered from within the basalt section. Bedding indicates dips of $25^{\circ}$ to $30^{\circ}$; this immediately suggests that the basement section has been tilted to this extent. Interestingly enough, though, magnetic inclinations within both the basalt and the limestone give the expected dipole value, and this would seem to indicate that no tilting has taken place. Another explanation may be that the remanence is post-tilting CRM. But Day et al. (this volume) found that most of the samples they studied from Hole $412 \mathrm{~A}$ were only slightly oxidized; these same samples were also highly viscous, which suggests that the remanence is overprinted by VRM. It does not seem possible to decide from the seismic or drilling data whether the basement is dipping or not.

The interlayered limestones also show slickensides (Varet and Choukroune, this volume). The fault planes are 
generally parallel to bedding and indicate vertical and right-lateral movement, whereas left-lateral movement is expected in the transform section of fracture zone $B$. We may have sampled a conjugate Riedel shear (Wilcox et al., 1973) in the fracture zone. These shears form at high angles to the main shear direction, and exhibit the opposite sense of movement.

Site 413 is on the south side of the fracture zone $B$ valley, along strike from Site 412 . The predicted age here is about $3.4 \mathrm{~m} . \mathrm{y}$., but the oldest sediments recovered are only lower Pleistocene, as at Site 412 . Only 39.5 meters of basement was drilled, and the rocks in that interval are pebbles, boulders, and cobbles of either hyaloclastite or compact basalt. Many of the clasts are of variable petrology; they are also rounded and rimmed with brown alteration zones. All of which suggests that the basement here is actually a talus pile. In contradiction to this, however, the only two available oriented magnetic samples give magnetic inclinations near the dipole value. In addition, the geochemistry falls into two well-defined and highly contrasted units, with a clear stratigraphic relation to one another. This seems unlikely in a pure talus pile. Talus and thin flows may be interlayered here, or, the talus may have been remagnetized. Some of the paleomagnetic samples are highly oxidized (Day et al., this volume), suggesting a CRM, but there are only a very few such samples.

Since Site 413 is apparently the same age as Site 412 , perhaps that basement at both sites originated from the northern crustal accretion zone. The deeper basement at 413 may be around $3.4 \mathrm{~m}$.y. old, but as the site moved east out of the transform zone, it may have been flooded by flows from the northern spreading center.

Overall, the observations at Sites 412 and 413 reveal some surprising facts about these fracture zones: the rocks are fresh and not different from those in the rift mountains, hydrothermal alteration is not evident, the rocks are essentially undeformed, and the stratigraphically highest rocks in the valley floor originated from the closest accretion zone.

\section{ACKNOWLEDGMENTS}

We would like to thank our shipboard colleagues for their thorough work and helpful discussions. Greg Crandall helped with the data analysis, and Robert Detrick and John Sclater reviewed an earlier version of the manuscript.

\section{REFERENCES}

ARCYANA, 1975. Transform fault and rift valley from bathyscaph and diving saucer, Science, v. 190, p. 108.

Detrick, R. S. and Crough, S. T., 1978. Island subsidence, hot spots and lithospheric thinning, J. Geophys. Res., v. 83, p. 1236.

Detrick, R. S., Mudie, J. D., Luyendyk, B. P., and Macdonald, K. C., 1973. Near-bottom observations of an active transform fault (Mid-Atlantic Ridge at $37^{\circ} \mathrm{N}$ ), Nature, v. 246, p. 59.
Fox, P. J., Scrieber, E., Rowlett, H., and McCamy, K., 1976. The geology of the Oceanographer fracture zone: A model for fracture zones, J. Geophys. Res., v. 81, p. 4117.

Heirtzler, J. R., Dickson, G. O., Herron, E. M., Pitman, W. C., III, and Le Pichon, X., 1968. Marine magnetic anomalies, geomagnetic field reversals, and motions of the ocean floor and continents, J. Geophys. Res., v. 73, p. 2119.

Kidd, R. G. W., 1977. The nature and shape of the sources of marine magnetic anomalies, Earth Planet. Sci. Lett., v. 33, p. 310 .

Kristoffersen, Y and Talwani, M., 1977. Extinct triple junction south of Greenland and the Tertiary motion of Greenland relative to North America, Geol. Soc. Am. Bull., v. 88, p. 1037.

La Brecque, J. L., Kent, D. V., and Cande, S. C., 1977. Revised magnetic polarity time scale for Late Cretaceous and Cenozoic time, Geology, v. 5, p. 330.

Moore, J., 1970. Water content of basalt erupted on the ocean floor, Contrib. Mineral. Petrol., v. 28, p. 272.

Moore, J. G. and Schilling, J. G., 1973. Vesicles, water and sulfur in Reykjanes Ridge basalts, Contrib. Mineral. Petrol., v. 41 , p. 105 .

Parsons, B. and Sclater, J. G., 1977. An analysis of the variation of ocean floor bathymetry and heat flow with age, J. Geophys. Res., v. 82, p. 803

Schrader, H. C., Bjørklund, K., Manum, S., Martini, E., and van Hinte, J., 1976. Cenozoic biostratigraphy, physical stratigraphy and paleooceanography in the Norwegian-Greenland Sea, DSDP Leg 38 paleontological synthesis. In Talwani, M., Udintsev, G., et al., Initial Reports of the Deep Sea Drilling Project, v. 38: Washington (U.S. Government Printing Office), p. 1197-1212.

Sclater, J. G., Lawver, L. A., and Parsons, B., 1975. Comparison of long-wavelength residual elevation and free air gravity anomalies in the North Atlantic and possible implications for the thickness of the lithospheric plate, J. Geophys. Res., v. 80, p. 1031.

Talwani, M., and Eldholm, O., 1977. Evolution of the Norwegian-Greenland Sea, Geol. Soc. Am. Bull., v. 88, p. 969.

Talwani, M., and Udintsev, G., et al., 1976. Initial Reports of the Deep Sea Drilling Project, v. 38: Washington (U.S. Government Printing Office).

Talwani, M., Windisch, C. C., and Langseth, M. G., 1971. Reykjanes Ridge crest: A detailed geophysical study, $J$. Geophys. Res., v. 76, p. 473.

Vogt, P. R. and Avery, D. E., 1974. Detailed magnetic surveys in the northeast Atlantic and Labrador Sea, J. Geophys. Res., v. 79, p. 363 .

Vogt, P. R. and Johnson, G. L., 1973. A longitudinal seismic reflection profile of the Reykjanes Ridge: Part II - Implications for the mantle hot spot hypothesis, Earth Planet. Sci. Lett., v. 18, p. 49.

Whitmarsh, R. B. and Laughton, A. S., 1976. A long-range sonar study of the Mid-Atlantic Ridge crest near $37^{\circ} \mathrm{N}$ (FAMOUS area) and its tectonic implications, Deep-Sea Res., v. 23, p. 1005 .

Wilcox, R. E., Harding, T. P., and Seely, D. R., 1973. Basic wrench tectonics, Am. Assoc. Petrol. Geol. Bull., v. 57, p. 74 . 